http://jmscr.igmpublication.org/home/

ISSN (e)-2347-176x ISSN (p) 2455-0450

crossref DOI: https://dx.doi.org/10.18535/jmscr/v8i11.18

Journal Of Medical Science And Clinical Research

\title{
Immunohistochemistry Profile of Breast Cancer Patients from 2010 to 2014 in National Cancer Institute, Misurata, LIBYA
}

\author{
Authors \\ R. Elamyal, M. Elfagieh, Naji Zubia and W. Zwawi \\ *Corresponding Author \\ R.Elamyal \\ Surgical Oncology Department, National Cancer Institute, Misurata, LIBYA
}

\begin{abstract}
Introduction: breast cancer is the most common cancer in women. More than one million women are affected by this disease worldwide. Estrogen receptor (ER), progesterone receptor $(P R)$ and Her-2 (Human Epidermal growth factor receptor) analysis have been accepted as established procedures in the routine management of patients with breast cancer.

Aim of our study is to to evaluate the estrogen receptor (ER), progesterone receptor (PR) and Her-2 expression in breast carcinomas by immunohistochemistry and clinicopathological parameters like patient's age, histological grade in the patients registered in our institute between 2010 to 2014.

Methods: retrospective study of 78 female invasive breast carcinomas registered in our Institute from January 2010 to Dec 2014.

Results: the age of the patients ranged from 24 to 80 years, with a mean of 48.5 , and the majority of the tumors were T2 invasive ductal carcinoma. Triple-negative breast cancers constituted $25 \%$ of our cases and were most commonly grade 2. So we conclude that our group has a smaller number of patients but generally the hormonal receptor expression appears to be lower in our group of patients compared to the West. Further larger size studies are needed for better evaluation.

Keywords: Breast, triple negative.
\end{abstract}

\section{Introduction}

Worldwide breast cancer is the most frequent cancer in women and represents the second leading cause of cancer death among women (after lung cancer) ${ }^{[1],[2]}$. There are numerous risk factors for breast cancer. Important risk factors are age, age at menarche/menopause, parity, duration of breast-feeding, changes in breast, genetic, nutritional, environmental and hormone factors. Despite breast cancer risk factors being known, in $50 \%$ of women the risk factors are not detected ${ }^{[3]}$. Determination of estrogen receptor (ER), progesterone receptor (PR), and human epidermal growth factor receptor-2 (HER2) status in patients with breast cancer is now considered a standard due to their predictive and prognostic implications ${ }^{[4]}$. Breast cancer is a hormone dependant tumor prototype and one-third of patients respond to endocrine therapy. Human epidermal receptor-2/neu (HER-2/neu) gene amplification occurs in $20-30 \%$ of breast cancers and it is associated with poor prognosis, lower response to hormone therapy and chemotherapy. HER-2/neu positive breast cancer predicts 


\section{JMSCR Vol||08||Issue||11||Page 103-106||November}

response to anti-HER-2/neu antibody ${ }^{[5]}$. Despite all the advances, the management of breast cancer is still a controversial topic. This obviously is the reason why it continues to be the focus of intense basic and clinical research. So, the objective of this study was to determine receptor status and other morphological prognostic parameters including age in breast cancer cases operated on in our Institute from 2010 till 2014.

\section{Methods \& Materials}

Retrospective study of (78) seventy eight female invasive breast carcinomas registered in our
Institute during the period from January 2010 to Dec 2014. Data were retrieved from the cancer registry medical records of the patients including inaddition to demographic data, cancer histologic type, cancer grade, stage ER, PR and HER2neu expression.

\section{Results}

The age of the patients ranged from 24 to 80 years, with a mean of 48.5 , and all of them were females. Age group 30-39yrs and 40-49yrs are most commonly affected with breast cancer (table $1)$.

Table (1): Show age distribution of breast cancer cases

\begin{tabular}{|c|c|c|c|c|c|}
\hline 20-29yrs & 30-39yrs & 40-49yrs & 50-59yrs & 60-69yrs & 70yrs and Above \\
\hline $1 \%$ & $30.7 \%$ & $28.2 \%$ & $14 \%$ & $10.2 \%$ & $15.4 \%$ \\
\hline
\end{tabular}

\section{Types of histopathology and histological} grades of breasts specimens:

Invasive ductal carcinoma (IDC) were found in $69(88.46 \%)$ cases and invasive lobular
carcinoma(ILC) in 3(3.8\%). Overall (48/78; $61.5 \%)$ were histological grade $2,23 \%$ grade $3,16,6 \%$ grade 1 . Table 2 and table 3 .

Table (2): Histopathology types of breast cancer

\begin{tabular}{lcc} 
Histopathology & Result & No \% \\
\hline Invasuve ductal carcinoma & $69 / 78$ & $\mathbf{8 8 . 4 6 \%}$ \\
Invasive lobuar carcinoma & $03 / 78$ & $03.80 \%$ \\
Mucinous & $03 / 78$ & $03.80 \%$ \\
Papillary & $01 / 78$ & $01.03 \%$ \\
Cribriform & $01 / 78$ & $01.03 \%$ \\
Secretory & $01 / 78$ & $01.03 \%$ \\
\hline
\end{tabular}

Table (3): Histologic grades of breast cancer

\begin{tabular}{lcc} 
Histologic & GRADE & No \% \\
\hline Well differentiated (G1) & $13 / 78$ & $16.66 \%$ \\
Moderately differentiated (G2) & $48 / 78$ & $61.53 \%$ \\
Poorly differentiated (G3) & $18 / 78$ & $23.07 \%$ \\
TOTAL & $\mathbf{7 8}$ & 100
\end{tabular}

The prevalence of ER, PR and HER-2/neu expression were $57.69 \%, 60.25 \%$ and $25.60 \%$, respectively. Table 4.

Table(4): Receptor status of breast cancer cases.

\begin{tabular}{lcc} 
Immunohistochemistry & result & No \% \\
\hline Her2 & 20 & $\mathbf{2 5 . 6 0 \%}$ \\
ER & 45 & $\mathbf{5 7 . 6 9 \%}$ \\
PR & 47 & $\mathbf{6 0 . 2 5 \%}$ \\
Triple negative & 20 & $\mathbf{2 5 . 6 0 \%}$ \\
\hline
\end{tabular}




\section{Discussion}

The age of the women at diagnosis of breast cancer varied from 24 to 80 years with a mean of 48.5 years. Most of the patients $(n=46,58.9 \%)$ were in the 30-39 and 40-49 age groups. Our results corroborate the studies carried out in Bangui by Koffi et al. (2004) but slightly above the frequency reported by Marianne Dubard-Gault in $2014^{[6,7,8]}$. In Europe and the US, the average age of women with breast cancer at the time of diagnosis was about 60 years, while in third world countries was earlier than that which could be explained by an information and awareness deficit on breast cancer finally by a lot of screening in women age 50 and over in the US and Europe ${ }^{[9]}$. These findings suggest that in Africa and other third world countries, breast cancer affects women at an earlier age and at an advanced stage of diagnosis and has poor outcomes. Eighty eight point $4 \%(n=69,88.46 \%)$ of all cases were invasive ductal carcinoma, followed by invasive lobular carcinoma $(n=03,3.8 \%) . n$ Cameroon (2013) and Ghana (2015), Engbang et al., and Edmund et al., found $74.3 \%$ and $91.6 \%$ of invasive ductal carcinomas followed by $4.3 \%$ and $3.1 \%$ of invasive lobular carcinoma ${ }^{[10,11]}$. The same trends were observed in previous study carried out in Bangui by Koffi et al., in $2004^{[6]}$. However, the absence of diagnosis of DCIS could be due to the lack of mammography which is the only tool for early detection of breast cancer cases. There was a high proportion of grade II in the order of $61.53 \%$ followed by grade III $(23.07 \%)$ and grade I (16.66\%). Our study result is similar to a study done by Koffi et al. in Bangui, noted that the grade II tumours were the most common with $58.4 \%$ of cases, while tumours grade I and II were in the same proportion $(20.8 \%)^{[6]}$. These findings differ from those reported by Meye et al.(2004) where Grade II tumours were less common than classes III and $\mathrm{I}^{[12]}$. In our study, a major proportion of the patients were hormone positive; ER (57.69\%), PR $(60.69 \%)$.The percentage of HER2-positive cases in our study is more or less similar to that described in the Western literature ${ }^{[13]}$. The reason for this relative uniformity in HER2 status worldwide is unclear. Triple negative breast cancer (TNBC) comprise 10\%-20\% of all breast cancers in the Western literature and are the most aggressive subtype with poor prognosis ${ }^{[14]}$ In our study, it combrises $25 \%$ of cases. The higher TNBC numbers have been attributed to tumor biology and younger age of patients ${ }^{[15]}$. The finding of increased TNBC in certain countries suggests that intrinsic genetic susceptibility/ ethnicity may play a role ${ }^{[16]}$. So we conclude thatour group has a smaller number of patients but generally the hormonal receptor expression appears to be lower in our group of patients compared to the West. Further larger size studies are needed for better evaluation.

\section{References}

1. Dumitrescu RG, Cotarla I. Understanding breast cancer risk-where do we stand in 2005? J Cell Mol Med 2005;9:208-21.

2. Rastelli F, Crispino S. Factors predictive of response to hormone therapy in breast cancer. Tumori 2008;94:370-83.

3. Pesic I, Krstic M, Pavlovic M, Ilic D, Dimitrios K. Hormone sensitivity in women with breast cancer. Acta Medica Medianae 2007;46:25-30

4. Murthy NS, Chaudhry K, Nadayil D, Agarwal UK, Saxena S. Changing trends in incidence of breast cancer: Indian scenario. Indian J Cancer 2009;46:73-4.

5. Huang HJ, Neven $P$, Drijkoningen $M$, Paridaens R, Wildiers H, Van Limbergen E, et al. Hormone receptors do not predict the Her2/neu status in all age groups of women with an operable breast cancer. Ann Oncol 2005;16:1755-65.

6. Koffi B, Sepou A, Doui D, Goumba C, Djabanga S. Epidemiological and histological characteristics of breast cancers in Bangui. Méd Afr Noire. 2004; $51: 112-4$. 
7. Li T, Mello-Thoms C, Brennan PC. Descriptive epidemiology of breast cancer in China: incidence, mortality, survival and prevalence. Brest Cancer Res Treat. 2016;159:395-406.

8. Dubard-Gault M. Breast cancer in women under 50 years old in Reunion between 2005 and 2010. Thesis of Medical Science 2013. In: Human Health and pathology [ dumas-00967404]

2014. https://dumas.ccsd.cnrs.fr/dumas0096740. 2014. Assessed 11 Nov 2015. [French Document

9. Ly M, Antoine M, André F, Callard P, Bernaudin JF, Diallo DA. Breast cancer in sub-Saharan African women: review. Bull Cancer. 2011;98:797-806.

10. Ndamba Engbang JP, Essome H, Mve Koh V, Simo G, Sime Essam JD, Sone Mouelle $\mathrm{A}$, et al. Breast cancer in Cameroon, epidemiological profile histoepidemiological: about 3044 cases. Pan African Med J. 2015;21:7269.

11. Edmund DM, Naaeder SB, Tettey Y, Gyasi RK. Breast cancer in Ghanaian women: what has changed? Am J Clin Pathol. 2013;140:97-102.

12. Meye JF, Ngomo KM, Diallo I. Breast cancer hospital in Libreville. Méd Afr Noire. 2004;51:479-82.

13. Goldhirsch A, Winer EP, Coates AS, Gelber RD, Piccart-Gebhart M, Thürlimann B, et al. Personalizing the treatment of women with early breast cancer Highlights of the St. Gallen International Expert Consensus on the Primary Therapy of Early Breast Cancer 2013. Ann Oncol 2013;24:2206-23

14. Gupta A, Jain J, Kumar A, Kumar S, Wadhwa N. Triple negative breast cancer - An overview and review of literature. Asian J Med Sci 2012;3:16-20.
15. Desai SB, Moonim MT, Gill AK, Punia RS, Naresh KN, Chinoy RF, et al. Hormone receptor status of breast cancer in India: A study of 798 tumours. Breast 2000;9:267-70.

16. Kakarala M, Rozek L, Cote M, Liyanage S, Brenner DE. Breast cancer histology and receptor status characterization in Asian Indian and Pakistani women in the U.S. - A SEER analysis. BMC Cancer 2010;10:191. 